Research Journal of Applied Sciences 14 (8): 243-249, 2019

ISSN: 1815-932X

(C) Medwell Journals, 2019

\title{
Activated Bentonite: Low Cost Adsorbent to Reduce Mercury Content in A Solution
}

\author{
Muhammad Naswir, Yusnelti Desfaurnatalia, L. Septiarini and Yudha Gusti Wibowo \\ Universitas Jambi (UNJA), Jambi, Indonesia
}

\begin{abstract}
The purpose of this study is to find the best activator for bentonite to reduce the mercury content in a solution. Bentonite was activated by $\mathrm{HCl}, \mathrm{H}_{3} \mathrm{PO}_{4}, \mathrm{NaCl}, \mathrm{ZnCl}_{2}, \mathrm{NaOH}$ and $\mathrm{KOH}$ use different concentration such as $0.5,1.0$ and $1.5 \mathrm{M}$. Activated bentonite has been characterized by $\mathrm{x}$-ray diffraction, scanning electron microscope with energy dispersive spectroscopy and atomic absorption spectrometry. Bentonite characterization showed that bentonite contains kaolinite, montmorillonite, quartz and cristobalite. Activated bentonite has bigger pores than natural bentonite. Atomic absorption spectrometry showed that $\mathrm{H}_{3} \mathrm{PO}_{4}, \mathrm{HCl}$, $\mathrm{NaCl}, \mathrm{ZnCl}_{2}, \mathrm{NaOH}$ and $\mathrm{KOH}$ can reduce the mercury around 99.99, 99.87, 97.48, 9.24, 99.81 and $99.86 \%$. Thus, best activator for activated bentonite as a low-cost adsorbent is $\mathrm{H}_{3} \mathrm{PO}_{4}$.
\end{abstract}

Key words: Bentonite, activated bentonite, activator, mercury, natural bentonite, low-cost adsorbent

\section{INTRODUCTION}

Heavy metals is dangerous material (Gai et al., 2019). Mercury is a volatile metal in liquid phase at $25^{\circ} \mathrm{C}$ and easily to react with another compound (Aerts et al., 2014). Mercury can give some impact for environment and human health such as visual impairment, poisoning and death (Bernhoft, 2012). Thus, removal mercury from water has become an urgent problem.

Mercury is an impact of industrial activities such as gold mining, acid mine drainage on coal mining and another else (Kahhat et al., 2019; Li et al., 2012; Mason et al., 2019). In gold mining, mercury was used to draw gold granules. This activity will give some negative impacts in environment. Contaminated water by mercury can reduce use adsorption method (Liu et al., 2018). For the complete removal of mercury from solution, numerous techniques such as chemical precipitation, ion exchange, coagulation, reduction, membrane filtration and adsorption have been explored, among these techniques, adsorption is deemed to be most practical and economical approach (Fu and Wang, 2011). The identification of efficient sorbents is the key to designing a good adsorption process. In this context, bentonite have received considerable attention as sorbent caused bytheir widespread, exceptional water filtration capabilities, availability and highheavy metal adsorption capabilities (Jimtaisong and Sarakonsri, 2019).

Activated bentonite which are cheap and environmentally benign sorbents (Naswir et al., 2019) have been extensively used for mercury adsorption. Indonesian bentonite deposit is 380 million of tons are spreading in Sumatera and Java Island. Jambi province have 650 ha of bentonite as potential low-cost sorbent (Naswir et al., 2019). Bentonite have 2 layers that give impact for good ion exchange.
Bentonite can activation use chemical and physical methods. Chemical activation use acid or base solution such as $\mathrm{CaCl}_{2}, \mathrm{Ca}(\mathrm{OH})_{2}, \mathrm{NaCl}, \mathrm{MgCl}_{2}, \mathrm{HNO}_{3}, \mathrm{HCl}$, $\mathrm{Ca}_{3}\left(\mathrm{PO}_{4}\right)_{2}, \mathrm{H}_{3} \mathrm{PO}_{4}, \mathrm{ZnCl}_{2}$. Every activator give different impact for pores and surface area, activation made ion exchange (cation with $\mathrm{H}^{+}$). Activated bentonite use acid activators make biggest pores and surface area than base activation, it will give an impact for better sorption (Toor et al., 2014, 2015).

\section{MATERIAL AND METHODS}

Characterization and activators: Bentonite was collected from Sungai Rengas, Jambi Province, Indonesia. Activated bentonite characterized use x-ray diffraction, scanning electron microscope with energy dispersive spectroscopy and atomic absorption spectrometry. Acid activator used for bentonite activation are $\mathrm{Hg}\left(\mathrm{NO}_{3}\right)_{2}$, $\mathrm{H}_{3} \mathrm{PO}_{4}, \mathrm{ZnCl}_{2}, \mathrm{NaCl}, \mathrm{NaOH}$, dan $\mathrm{KOH}$.

Bentonite preparation and activation: The bentonite used in this study were produced by pyrolizing natural bentonite. Firstly, bentonite prepared to reduce water content in furnace at $105^{\circ} \mathrm{C}$ for $24 \mathrm{~h}$. Bentonite was pyrolized at temperature of $200^{\circ} \mathrm{C}$ for a hour. The $50 \mathrm{~g}$ bentonite with particle size is 100 mesh was mix with activators in Erlenmeyer. The $200 \mathrm{~mL}$ of activators with different concentration $(0.5,1.0$ and $1.5 \mathrm{M})$ mixed in $50 \mathrm{~g}$ of bentonite in Erlenmeyer. These treatment is done for enlarge the pores and surface area of bentonite. After that bentonite has filtered and washed out to reduce activators fom the bentonite. Distilled water has chosen because have neutral $\mathrm{pH}$, so, it will prevent the reaction between bentonite and activators. The resulting residue is dried by heating. In the heating process after activation, the activating material enters between layers and then opens 


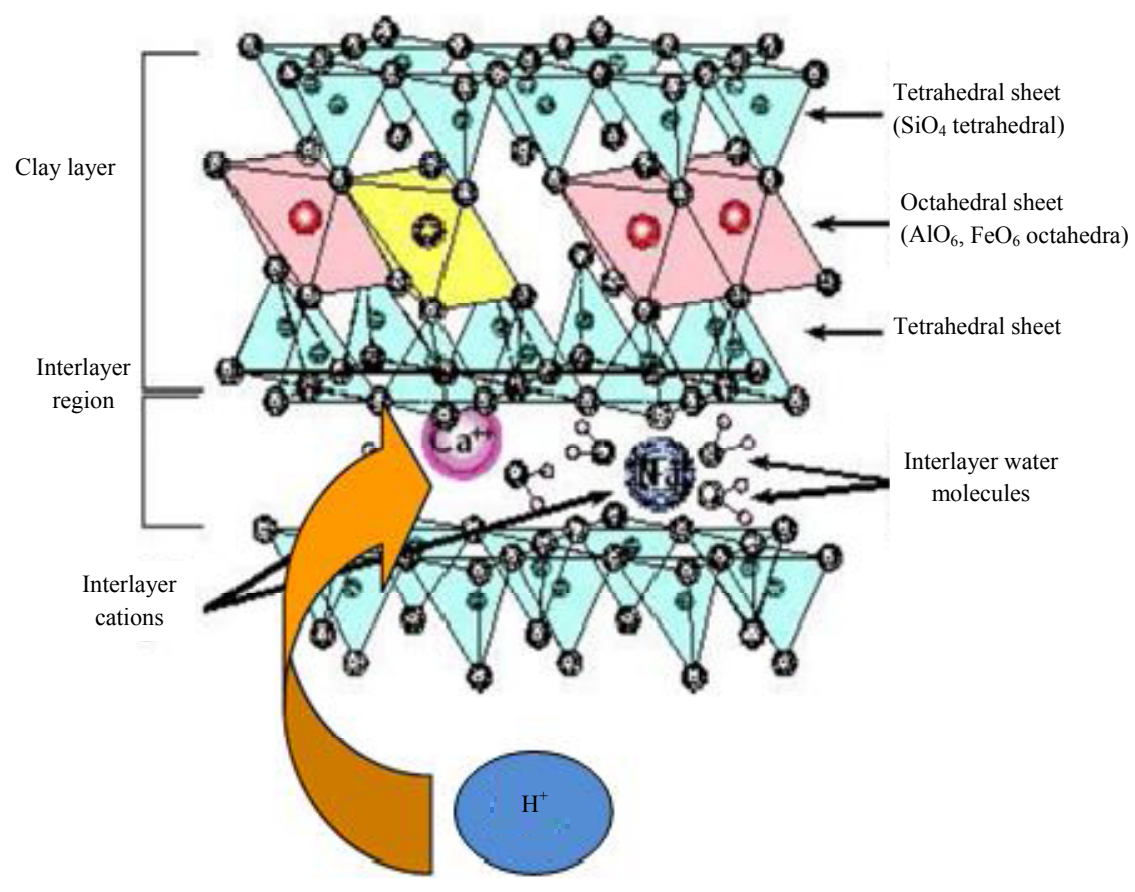

Fig. 1: Bentonite reaction use $\mathrm{HCl}$ and $\mathrm{H}_{3} \mathrm{PO}_{4}$

the closed surface. Bentonite activation used $\mathrm{HCl}$ and $\mathrm{H}_{3} \mathrm{PO}_{4}$ to change ion of $\mathrm{H}^{+}$by releasing $\mathrm{Al}^{3+}, \mathrm{Fe}^{3+}$ dan $\mathrm{Mg}^{2+}$ (Fig. 1). Ion exchange of activated bentonite with $\mathrm{HCl}$ and $\mathrm{H}_{3} \mathrm{PO}_{4}$. Activated bentonite was mixed in $20 \mathrm{~mL}$ of $5 \mathrm{ppm} \mathrm{Hg}\left(\mathrm{NO}_{3}\right)_{2}$ and mix by magnetite stirrer with $200 \mathrm{rpm}$ for $30 \mathrm{~min}$.

\section{RESULTS AND DISCUSSION}

Bentonite activation: Activation of bentonite purpose to maximization of bentonite sorption. Chemical activation use $\mathrm{H}_{3} \mathrm{PO}_{4}, \mathrm{HCl}, \mathrm{ZnCl}_{2}, \mathrm{NaCl}, \mathrm{NaOH}$, dan $\mathrm{KOH}$ with different concentrations. $\mathrm{HCl}$ and $\mathrm{H}_{3} \mathrm{PO}_{4}$ can change the minerals $\left(\mathrm{Ca}^{2+}\right.$ dan $\left.\mathrm{Mg}^{2+}\right)$ in interlayers with $\mathrm{H}^{+}$. Chemical activation use $\mathrm{HCl}$ and $\mathrm{H}_{3} \mathrm{PO}_{4}$ on bentonite bellow:

$$
\begin{aligned}
\mathrm{Al}_{4} \mathrm{Si}_{8} \mathrm{O}_{20}(\mathrm{OH})_{4}+3 \mathrm{H}^{+} \rightarrow & \mathrm{Al}_{3} \mathrm{Si}_{8} \mathrm{O}_{20}(\mathrm{OH})_{2}+\mathrm{Al}^{3+}+2 \mathrm{H}_{2} \mathrm{O} \\
\downarrow & \mathrm{H}^{+}
\end{aligned}
$$

This reaction inform Al has changed to hydroxyl structure that give an impact of change of octahedral to tetrahedral. Changed of octahedral to tetrahedral made the crystal lattice is negatively charged, negative charged will neutralizing by alkali in bentonite (Krupskaya et al., 2019). Activated bentonite used $\mathrm{ZnCl}_{2}$ and $\mathrm{NaCl}$ make an exchange of $\mathrm{Zn}$ and $\mathrm{Na}$. $\mathrm{ZnCl}_{2}$ is hydrating agent. Hydrating agent can make biggest pores and surface of bentonite. Bentonite was soaked in deionization solution for reduce bentonite pores from another residues. $\mathrm{NaCl}$ is an effective activator because easy to find and non-toxic. $\mathrm{NaCl}$ in solution phase will be dissociated and made positive and negative ions are $\mathrm{Na}^{+}$and $\mathrm{Cl}^{-}$. Na will be surrounded by negative partial from water and $\mathrm{Cl}^{-}$will be surrounded by positive partial by water molecules.

Base activators $(\mathrm{NaOH}$ and $\mathrm{KOH})$ will give an impact for silica and alumina in bentonite reacted with base solution and made salt product. These activators can reduce impurity and make biggest pores and surface area. Therefore this treatment can improve sorption ability (Pawar et al., 2016).

\section{Characterization}

$\mathrm{X}$-ray diffraction: $\mathrm{X}$-ray diffraction used to find peak of natural bentonite and activated bentonite and find the different of these peaks. X-ray diffraction of natural and activated bentonite informs that bentonite has created by kaolinite, montmorillonite, quartz and cristobalite. Samples were examined by using BRUKER D8 Advance Model $\mathrm{x}$-ray diffractometer with $\mathrm{Cu} \mathrm{K} \alpha$ radiation operated at $40 \mathrm{~mA}$ and $40 \mathrm{kV}$ with a 0.01 step size, Ni $\beta$-filter and Lynx-eye ${ }^{\circledR}$ position sensitive detector. Characterizations were made using randomly oriented grains. For this purpose, samples were finely grounded and put into an oven at $200^{\circ} \mathrm{C}$ for $1 \mathrm{~h}$ before analysis. Then, these samples were put into sample holders and a flat glass plate pressed by hand to obtain powder having a flat compact surface. The natural bentonite have high $2 \theta$ angles $\left(27^{\circ}\right)$ with counts almost 9000 (Fig. 2). Bulk 
Res. J. Applied Sci., 14 (8): 243-249, 2019

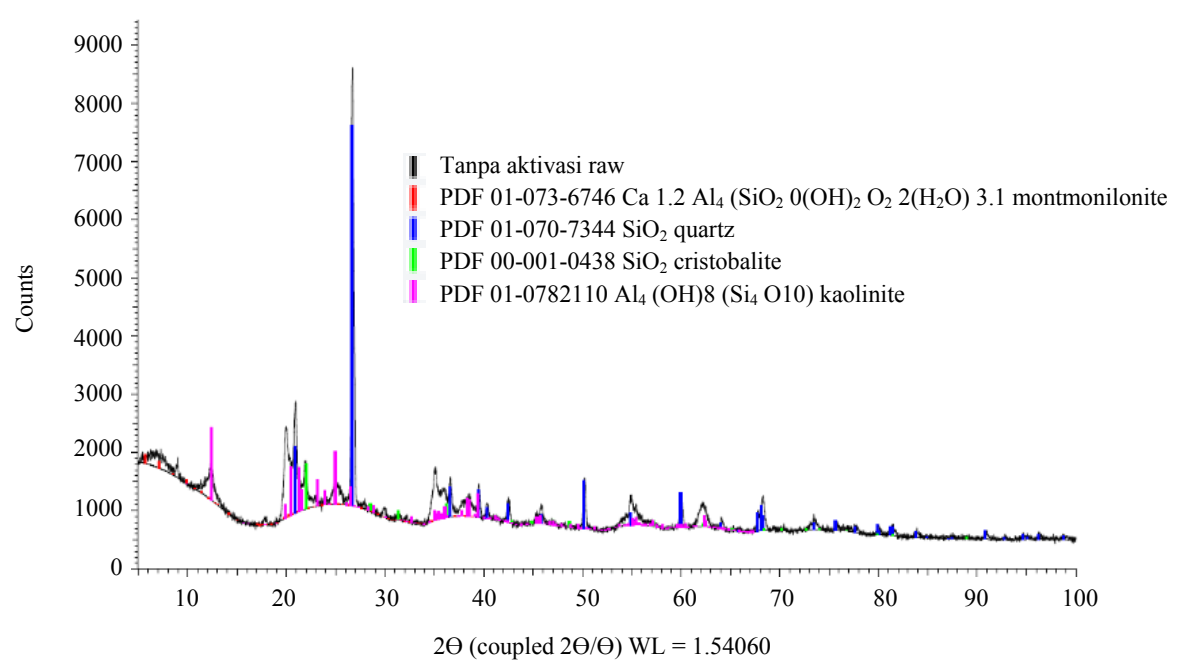

Fig. 2: XRD pattern of natural bentonite

samples were scanned between $5^{\circ}$ and $65^{\circ} 2 \theta$ range using a $1 \mathrm{~mm}$ divergent slit. Natural bentonite composed by montmorillonite (PDF 01-073-6746), quartz (PDF 01-070-7344), cristobalite (PDF 00-001-0438) and kaolinite (01-078-2110).

Activated bentonite use $\mathrm{HCl}, \mathrm{H}_{3} \mathrm{PO}_{4}$ and $\mathrm{ZnCl}_{2}$ has characterized by $\mathrm{x}$-ray diffraction. XRD pattern informs that activated bentonite use $\mathrm{ZnCl}_{2}$ have strong intensity than $\mathrm{ZnCl}_{2}$ and $\mathrm{H}_{3} \mathrm{PO}_{4}$. Intensity of activated bentonite by $\mathrm{HCl}, \mathrm{ZnCl}_{2}$ and $\mathrm{H}_{3} \mathrm{PO}_{4}$ activation is between 8000-9000 and $9000-1000$. The $2 \theta$ of $x$-ray diffraction is in $27^{\circ}$ in all of bentonites.

Activated bentonite used $\mathrm{H}_{3} \mathrm{PO}_{4}, \mathrm{HCl}, \mathrm{ZnCl}_{2}$ have minerals composition such as montmorillonite (Ca1.2.AI4 $\left.\left(\mathrm{Si}_{8} \mathrm{O}_{2(\mathrm{OH}) 2}\right)\right) \mathrm{O}_{2}$. The $2\left(\mathrm{H}_{2} \mathrm{O}\right)$, quartz $\left(\mathrm{SiO}_{2}\right)$, cristobalite $\left(\mathrm{SiO}_{2}\right)$ and kaolinite $(\mathrm{OH}) 8\left(\mathrm{Si}_{4} \mathrm{O}_{10}\right)$. Generally, all of bentonites does not have significant changed with the different treatment. These peaks inform that no strain caused no movement of peaks in diffraction line.

Scanning electron microscope with energy dispersive spectroscopy: Scanning electron microscope used to find pore sizes of bentonites. Scanning electron microscope showed that the texture of had a coarser surface, a more abundant pore structure and rich white spherical particles with diameters between 0.5 and $2 \mu \mathrm{m}$. Natural bentonite have smooth surface than activated bentonite, activated bentonite used $\mathrm{H}_{3} \mathrm{PO}_{4}$ and $\mathrm{ZnCl}_{2}$ have coarser surface than activated bentonite used $\mathrm{HCl}$ (Fig. 3). The different of pores in surface area caused by different activators. Activator can make surface area coarser and biggest pores, it will give an impact of ability sorption. The correspondence energy dispersive spectroscopy informs elements of bentonite such as $\mathrm{C}, \mathrm{O}, \mathrm{Na}, \mathrm{Mg}, \mathrm{Al}, \mathrm{Si}, \mathrm{Cl}, \mathrm{K}$, $\mathrm{Ca}, \mathrm{Ti}, \mathrm{Mn}, \mathrm{Fe}, \mathrm{Cu}, \mathrm{Zn}, \mathrm{P}$ and bentonites compounds such as $\mathrm{C}, \mathrm{MgO}, \mathrm{Al}_{2} \mathrm{O}_{3}, \mathrm{SiO}_{2}, \mathrm{Cl}, \mathrm{K}_{2} \mathrm{O}, \mathrm{CaO}, \mathrm{TiO}_{2}, \mathrm{MnO}, \mathrm{FeO}$, $\mathrm{CuO}, \mathrm{P}_{2} \mathrm{O}_{5} \mathrm{ZnO}$ and $\mathrm{Na}_{2} \mathrm{O}$. Note $\mathrm{A}$ is natural bentonite; $\mathrm{B}$ is activated bentonite use $\mathrm{H}_{3} \mathrm{PO}_{4} ; \mathrm{C}$ is activated bentonite
Table 1: Element of bentonites

\begin{tabular}{|c|c|c|c|c|}
\hline \multirow[b]{2}{*}{$\underline{\text { Elemenst }}$} & \multicolumn{4}{|c|}{ Sample of bentonites $(\%)$} \\
\hline & A & B & $\mathrm{C}$ & $\mathrm{D}$ \\
\hline$\overline{\mathrm{C}}$ & - & 4,77 & 14.24 & 14.83 \\
\hline $\mathrm{O}$ & 64.61 & 48.13 & 41 & 40.13 \\
\hline $\mathrm{Na}$ & - & - & - & 0.47 \\
\hline $\mathrm{Mg}$ & - & - & 0.11 & - \\
\hline $\mathrm{Al}$ & 12.25 & 13.30 & 17.79 & 13.09 \\
\hline $\mathrm{Si}$ & 20.29 & 23.92 & 20.62 & 23.66 \\
\hline $\mathrm{Cl}$ & - & - & 0.75 & 2.71 \\
\hline $\mathrm{K}$ & 0.68 & 1.08 & 0.04 & \\
\hline $\mathrm{Ca}$ & - & - & - & \\
\hline $\mathrm{Ti}$ & 0.25 & - & 0.4 & \\
\hline $\mathrm{Mn}$ & - & - & 0.25 & - \\
\hline $\mathrm{Fe}$ & 1.91 & 2.53 & 1.73 & 2.76 \\
\hline $\mathrm{Cu}$ & - & - & 3.08 & - \\
\hline $\mathrm{Zn}$ & - & - & - & 2.35 \\
\hline $\mathrm{P}$ & & 6.27 & & \\
\hline \multicolumn{5}{|c|}{ Component } \\
\hline $\mathrm{C}$ & - & 4.77 & 14.24 & 14.83 \\
\hline $\mathrm{MgO}$ & - & - & 0.19 & \\
\hline $\mathrm{Al}_{2} \mathrm{O}_{3}$ & 31.72 & 25.13 & 33.61 & 24.72 \\
\hline $\mathrm{SiO}_{2}$ & 62.93 & 51.17 & 44.11 & 50.62 \\
\hline $\mathrm{Cl}$ & - & - & 0.75 & 2.71 \\
\hline $\mathrm{K}_{2} \mathrm{O}$ & 1.21 & 1.3 & 0.04 & - \\
\hline $\mathrm{CaO}$ & - & - & 0.01 & - \\
\hline $\mathrm{TiO}_{2}$ & 0.61 & - & 0.66 & - \\
\hline $\mathrm{MnO}$ & - & & 0.32 & 3.55 \\
\hline $\mathrm{FeO}$ & 3.54 & 3.26 & 2.22 & \\
\hline $\mathrm{CuO}$ & - & - & 3.85 & - \\
\hline $\mathrm{P}_{2} \mathrm{O}_{5}$ & - & 14.38 & - & - \\
\hline $\mathrm{ZnO}$ & - & - & - & 2.92 \\
\hline $\mathrm{Na}_{2} \mathrm{O}$ & - & - & - & 0.64 \\
\hline
\end{tabular}

use $\mathrm{HCl}$ and; $\mathrm{D}$ is activated bentonite use $\mathrm{ZnCl}_{2}$ (Table 1). Elements changed of bentonite caused by pyrolysis and activation process by different activators. Undetected element caused by element too small and undetected by scanning electron microscope with energy dispersive spectroscopy such as carbon, natrium, magnesium, chlorine, calcium, manganese, copper, zinc and phosphor and $\mathrm{MgO}, \mathrm{Cl}, \mathrm{K}_{2} \mathrm{O}, \mathrm{CaO}, \mathrm{TiO}_{2}, \mathrm{MnO}, \mathrm{CuO}, \mathrm{P}_{2} \mathrm{O}_{5}, \mathrm{ZnO}$ and $\mathrm{Na}_{2} \mathrm{O}$. 

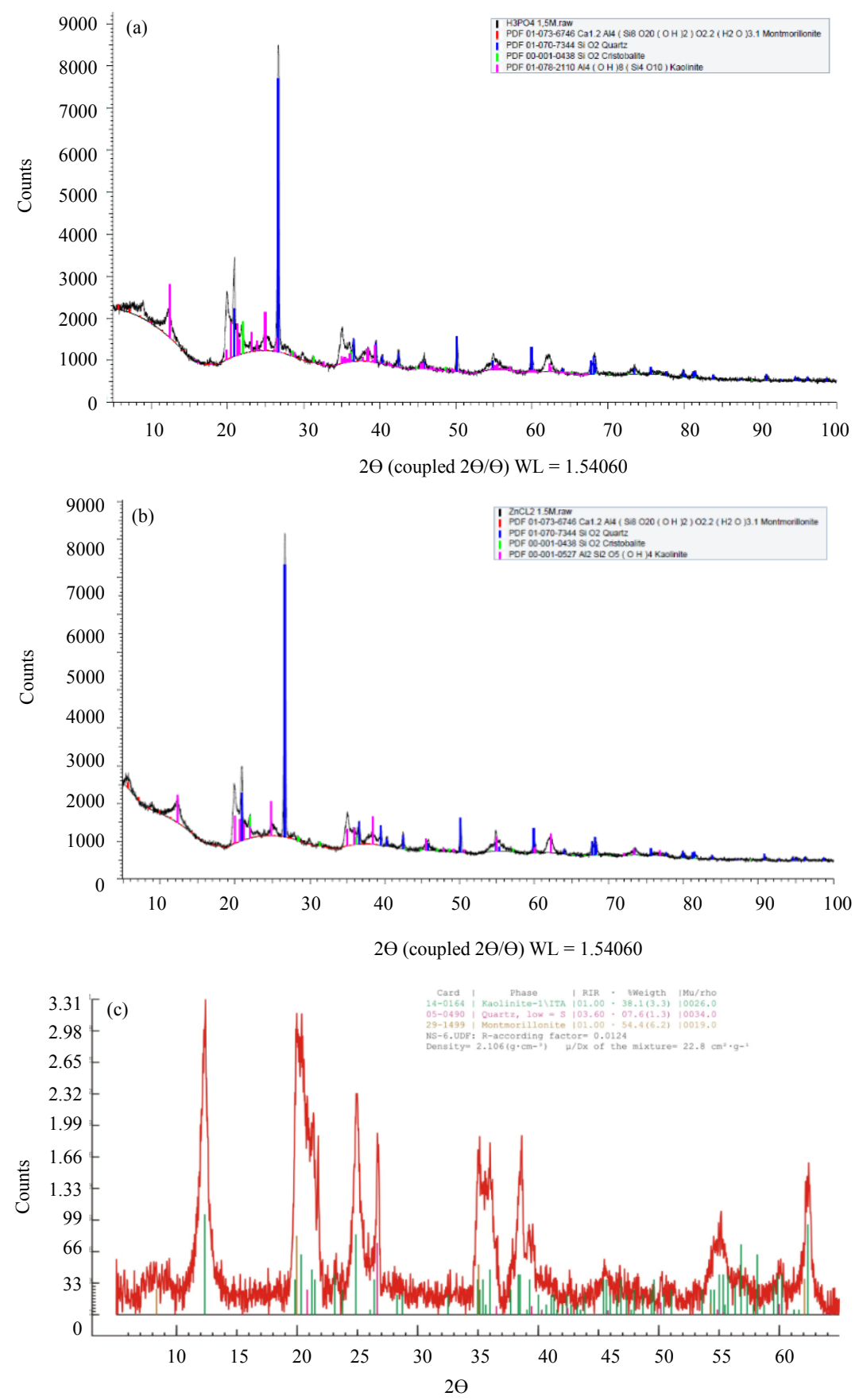

Fig. 3(a-c): XRD pattern of activated bentonite use (a) $\mathrm{H}_{3} \mathrm{PO}$, (b) $\mathrm{ZnCl}_{2}$ and (c) $\mathrm{HCl}$

Hg sorption by activated bentonite: Calibration curve was created to find calibration standard of $\mathrm{Hg}$. $\mathrm{Hg}$ was created by $1000 \mathrm{ppm}$ of $\mathrm{Hg}\left(\mathrm{NO}_{3}\right)_{2}$ was diluted to $100 \mathrm{ppm}$ (Fig. 4). Standard of $\mathrm{Hg}$ solution are $0,10,20,30$ and $40 \mathrm{ppm}$.

First calibration curve has created by five different ppm and have calibration curve $\mathrm{y}=0.2163 \mathrm{x}+0.00832$ with correlation coefficient (r) is 0.9991. Result of calibration curve showed linear line with standard concentration solution. It's inform more big concentration will need big adsorbent. This calibration curve will use to find sample concentration use equation:

$$
\mathrm{Y}=\mathrm{bx}+\mathrm{a}
$$




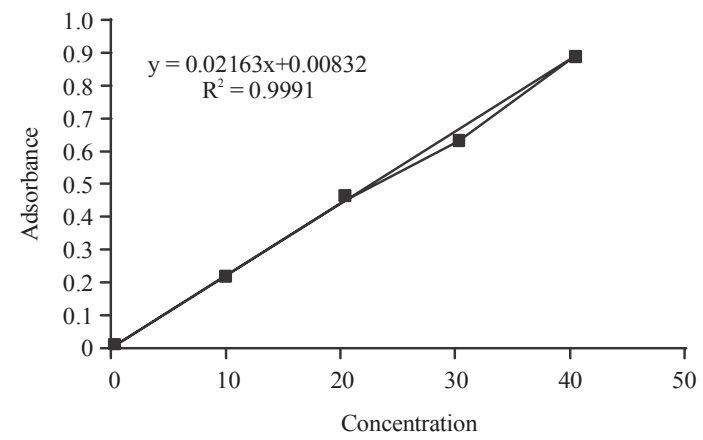

Fig. 4: Standard Calibration curve of $\mathrm{Hg}$

Table 2: Efficiency of $0.5 \mathrm{M} \mathrm{Hg}$

\begin{tabular}{|c|c|c|c|}
\hline \multirow[b]{2}{*}{ Activators } & \multicolumn{3}{|c|}{ Concentration (ppm) } \\
\hline & First & Last & Efficiency $(\%)$ \\
\hline$\overline{\mathrm{H}_{3} \mathrm{PO}_{4}}$ & 5 & 0.002016 & 99.96 \\
\hline $\mathrm{HCl}$ & 5 & 0.03376 & 99.33 \\
\hline $\mathrm{NaCl}$ & 5 & 0.125948 & 97.48 \\
\hline $\mathrm{ZnCl}_{2}$ & 5 & 0.137608 & 97.24783 \\
\hline $\mathrm{NaOH}$ & 5 & 0.009290 & 99.81 \\
\hline $\mathrm{KOH}$ & 5 & 0.138328 & 97.22 \\
\hline
\end{tabular}

Table 3: Efficiency of $1 \mathrm{M} \mathrm{Hg}$

\begin{tabular}{llll}
\hline & Concentration (ppm) & \\
& -------------------- \\
Activator & First & Last & Efficiency (\%) \\
\hline $\mathrm{H}_{3} \mathrm{PO}_{4}$ & 5 & 0.000853 & 99.98 \\
$\mathrm{HCl}$ & 5 & 0.006735 & 99.87 \\
$\mathrm{NaCl}$ & 5 & 0.484348 & 90.31 \\
$\mathrm{ZnCl}$ & 5 & 0.241523 & 95.16955 \\
$\mathrm{NaOH}$ & 5 & 0.116664 & 97.66 \\
$\mathrm{KOH}$ & 5 & 0.138809 & 97.22 \\
\hline
\end{tabular}

Table 4: Efficiency of 1.5 M Hg

\begin{tabular}{llll}
\hline & \multicolumn{2}{l}{ Concentration (ppm) } & \\
& --------------------- & Efficiency (\%) \\
Activator & First & Last & 99.99 \\
$\mathrm{H}_{3} \mathrm{PO}_{4}$ & 5 & 0.000332 & 98.87 \\
$\mathrm{HCl}$ & 5 & 0.056607 & 87.1 \\
$\mathrm{NaCl}$ & 5 & 0.644833 & 96.8974 \\
$\mathrm{ZnCl}_{2}$ & 5 & 0.15513 & 97.64 \\
$\mathrm{NaOH}$ & 5 & 0.117806 & 99.86 \\
$\mathrm{KOH}$ & 5 & 0.006567 & \\
\hline
\end{tabular}

Where:

b : Slope

a : Intercept

$\mathrm{Y}$ : Absorbance

$\mathrm{X}$ : Concentration

$r$ : Regression linear

Result of atomic absorption spectrometry of $\mathrm{Hg}$ in solution is more than $97 \%$ in $0.5 \mathrm{M}$ (Table 2), $90 \%$ in $1 \mathrm{M}$ (Table 3) and $87 \%$ in $1.5 \mathrm{M}$ (Table 4), these phenomena inform that every single activator did not have significant different, especially, $\mathrm{HCl}$ and $\mathrm{H}_{3} \mathrm{PO}_{4}$. It caused by acid activators will give an impact for ability sorption.

Equilibrium sorption of adsorbate is use to find sorption sioterm. The isotherm results of activated bentonite at a constatnt temperature of $105^{\circ}$ were analyzed using four important isotherms including the Langmuir, Freundlich, Temkin and Dubinin-Redushkevich (D-R) isotherm models.

The Langmuir adsorption model is based on the assumption that maximum adsorption corresponds to a saturated monolayer of solute molecules on the adsorbent surface with no lateral inter-action between the adsorbed molecules. The Langmuir adsorption isotherm has been successfully used inmanymonolayer adsorption processes. The expression of the Langmuir Model is given by equation:

$$
\mathrm{q}_{\mathrm{e}}=\frac{\mathrm{QobC}_{\mathrm{e}}}{1+\mathrm{bC}_{\mathrm{e}}}
$$

where, $\mathrm{q}_{\mathrm{e}}(\mathrm{mg} / \mathrm{g})$ and $\mathrm{C}_{\mathrm{e}}(\mathrm{mg} / \mathrm{L})$ are the amount of adsorbed adsorbate per unit mass of adsorbent and un-adsorbed adsorbate concentration in solution at equilibrium, respectively. The value of $\mathrm{Q}_{0}(\mathrm{mg} / \mathrm{g})$ is the maximum amount of adsorbate per unit mass of adsorbent to form a complete monolayer on the surface bound at high $\mathrm{C}_{\mathrm{e}}$ and $\mathrm{b}$ is a constant related to the affinity of the binding sites $(\mathrm{L} / \mathrm{mg})$. The Langmuir equation can be described by the linearized form

$$
\frac{\mathrm{C}_{\mathrm{e}}}{\mathrm{Q}_{\mathrm{e}}}=\frac{1}{\mathrm{Q}_{\mathrm{o}}} \mathrm{C}_{\mathrm{e}}+\frac{1}{\mathrm{Qob}}
$$

The essential characteristics of the Langmuir isotherm can be expressed in terms of a dimensionless constant separation factor RL that is given by the following equation:

$$
\mathrm{RL}=\frac{1}{1+\mathrm{bCo}}
$$

Where:

Co $(\mathrm{mg} / \mathrm{L})$ : Initial concentration of adsorbate b (L/mg) : Langmuir constant

There are four probabilities for the RL value: for favorable sorption, $0<R L<1$, for unfavorable sorption, $\mathrm{RL}>1$, for linear sorption, $\mathrm{RL}=1$, for irreversible sorption, $\mathrm{RL}=0$.

The Freundlich isotherm can be applied for non-ideal sorption on heterogeneous surfaces and multilayer sorption. The Freundlich equation is expressed as:

$$
\mathrm{q}_{\mathrm{e}}=\mathrm{K}_{\mathrm{f}} \mathrm{C}_{\mathrm{e}}{ }^{1 / n}
$$


Res. J. Applied Sci., 14 (8): 243-249, 2019

where $\mathrm{K}_{\mathrm{f}}$ and $\mathrm{n}$ are Freundlich constants with $\mathrm{K}_{\mathrm{f}}(\mathrm{mg} / \mathrm{g}$ $(\mathrm{L} / \mathrm{mg}) 1 / \mathrm{n}$ ) being the sorption capacity of the adsorbent and $\mathrm{n}$ giving an indication the favorability of the sorption process. Values of $\mathrm{n}>1$ represent favorable adsorption condition. To determine the constants $\mathrm{K}_{\mathrm{f}}$ and $\mathrm{n}$, the Freundlich equation can be described by the linearized form:

$$
\log \mathrm{q}_{\mathrm{e}}=\log \mathrm{K}_{\mathrm{f}}+\frac{1}{\mathrm{n}} \log \mathrm{C}_{\mathrm{e}}
$$

Temkin and Pyzhev considered the effects of some indirect adsorbate/adsorbate interaction on adsorption isotherms and suggested that because of these interactions the heat of adsorption of all the molecules in the layer would decrease linearly with coverage. The Temkin isotherm has been generally applied in the following form:

$$
\mathrm{q}_{\mathrm{e}}=\left(\frac{\mathrm{RT}}{\mathrm{b}}\right) \ln (\mathrm{ACe})
$$

and can be linearized as:

$$
\mathrm{q}_{\mathrm{e}}=\mathrm{B} \ln \mathrm{A}+\mathrm{B} \ln \mathrm{Ce}
$$

Where:

$\mathrm{B}=\mathrm{RT} / \mathrm{b}, \mathrm{b}$ : The Temkin constant related to heat of sorption $(\mathrm{J} / \mathrm{mol})$

A : : The Temkin isotherm constant $(\mathrm{L} / \mathrm{g})$

$\mathrm{R} \quad$ : The gas constant $(8.314 \mathrm{~J} / \mathrm{mol} \mathrm{K})$

$\mathrm{T} \quad$ : The absolute temperature $(\mathrm{K})$

The equilibrium data were also applied to the D-R model to determine the type of sorption (physical or chemical). The linear form of D-R isotherm is presented as the following equation:

$$
\operatorname{lnqe}=\operatorname{lnqm} \beta^{2}
$$

where, qe is the amount of aniline adsorbed onto per unit dosage of Cr-bentonite $(\mathrm{mol} / \mathrm{g}), \mathrm{qm}$ is the theoretical monolayer sorption capacity ( $\mathrm{mol} / \mathrm{g}), \beta^{2}$ is the constant ofthe sorption energy (mol2/J2) which is related to the average energy of sorption per mole of the adsorbate as it is transferred to the surface ofthe solid from infinite distance in the solution and $\beta$ is Polanyi potential which is described as:

$$
\beta=\mathrm{RT} \operatorname{In}\left(1+\frac{1}{\mathrm{C}_{\mathrm{e}}}\right)
$$

Where:

$\mathrm{T}$ : The solution temperature $(\mathrm{K})$

$\mathrm{R}$ : The gas constant and is equal to $8.314 \mathrm{~J} / \mathrm{mol} \mathrm{K}$.

The value of mean sorption energy, E $(\mathrm{kJ} / \mathrm{mol})$ can be calculated from D-R parameter $\beta$ as follows:

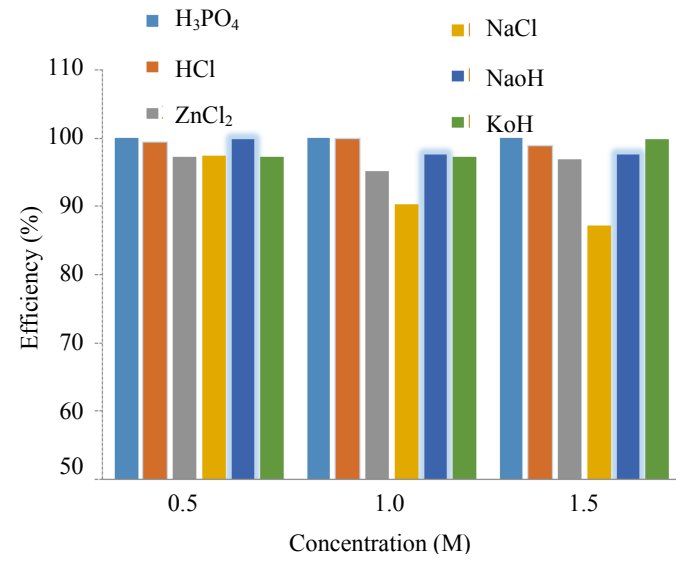

Fig. 5: Efficiency of activated bentonite

$$
E=\frac{1}{\sqrt{-2 \beta}}
$$

The value of mean sorption energy gives information about chemical and physical sorption. The $\mathrm{E}$ value ranges from 1-8 $\mathrm{kJ} / \mathrm{mol}$ for physical sorption and from $8-16 \mathrm{~kJ} / \mathrm{mol}$ for chemical sorption (Zheng et al., 2009).

Chemical activator in these research have three reaction such as mineral acid can reduce $\mathrm{Fe}_{2} \mathrm{O}_{3}, \mathrm{Al}_{2} \mathrm{O}_{3}$, $\mathrm{CaOdanMgO}$ in adsorbent pores. These phenomena make the pores bigger that make better surface area. Second reaction is $\mathrm{Ca}^{2+}$ and $\mathrm{Mg}^{2+}$ in surface area of crystal has changed with $\mathrm{H}^{+}$from acid mineral. Then, The $\mathrm{Ca}^{2+}$ and $\mathrm{Mg}^{2+}$ ion that changed with $\mathrm{H}^{+}$will change with $\mathrm{Al}^{3+}$ in acid mineral. As the result of this research best activator of bentonite is $\mathrm{H}_{3} \mathrm{PO}_{4}$ that can sorption $99.99 \%$ mercury in solution (Fig. 5)

\section{CONCLUSION}

Mercury is dangerous material that give negative impact for environment and human health. Bentonite as a local material can utilize as an adsorbent to reduce mercury in a solution. Bentonite has characterized use $\mathrm{x}$-ray diffraction and scanning electron microscope with energy dispersive spectroscopy. Bentonite has activated used $\mathrm{KOH}, \mathrm{NaOH}, \mathrm{HCl}, \mathrm{ZnCl}_{2}$ and $\mathrm{H}_{3} \mathrm{PO}_{4}$. These activators used to find the best activator for activated bentonite to reduce mercury $0.5 \mathrm{M}, 1.0 \mathrm{M}$ and $1.5 \mathrm{M}$ in a solution. Result of this study showed that $\mathrm{H}_{3} \mathrm{PO}_{4}, \mathrm{HCl}, \mathrm{NaCl}, \mathrm{ZnCl}_{2}, \mathrm{NaOH}$ and $\mathrm{KOH}$ can reduce the mercury around 99.99, $99.87,97.48,9.24,99.81$ and $99.86 \%$. Thus, best activator for activated bentonite as a low-cost adsorbent is $\mathrm{H}_{3} \mathrm{PO}_{4}$ 


\section{REFERENCES}

Aerts, A., S. Danaci, B.G. Prieto, J.V.D. Bosch and J. Neuhausen, 2014. Evaporation of mercury impurity from liquid lead-bismuth eutectic. J. Nucl. Mater., 448: 276-281.

Bernhoft, R.A., 2012. Mercury toxicity and treatment: A review of the literature. J. Environ. Public Health, Vol. 2012. 10.1155/2012/460508

Fu, F. and Q. Wang, 2011. Removal of heavy metal ions from wastewaters: A review. J. Environ. Manage., 92: 407-418.

Gai, K., A. Avellan, T.P. Hoelen, F. Lopez-Linares, E.S. Hatakeyama and G.V. Lowry, 2019. Impact of mercury speciation on its removal from water by activated Carbon and organoclay. Water Res., 157: 600-609.

Jimtaisong, A. and T. Sarakonsri, 2019. Chitosan intercalated bentonite as natural adsorbent matrix for water-soluble sappanwood dye. Int. J. Boil. Macromol., 129: 737-743.

Kahhat, R., E. Parodi, G. Larrea-Gallegos, C. Mesta and I. Vazquez-Rowe, 2019. Environmental impacts of the life cycle of alluvial gold mining in the Peruvian Amazon rainforest. Sci. Total Environ., 662: 940-951.

Krupskaya, V., L. Novikova, E. Tyupina, P. Belousov and O. Dorzhieva et al., 2019. The influence of acid modification on the structure of montmorillonites and surface properties of bentonites. Applied Clay Sci., Vol. 172, 10.1016/j.clay.2019.02.001.
Li, P., X. Feng, G. Qiu, L. Shang and S. Wang, 2012. Mercury pollution in Wuchuan mercury mining area, Guizhou, Southwestern China: The impacts from large scale and artisanal mercury mining. Environ. Int., 42: 59-66.

Liu, C., J. Peng, L. Zhang, S. Wang, S. Ju and C. Liu, 2018. Mercury adsorption from aqueous solution by regenerated activated carbon produced from depleted mercury-containing catalyst by microwave-assisted decontamination. J. Cleaner Prod., 196: 109-121.

Mason, R.P., Z. Baumann, G. Hansen, K.M. Yao, M. Coulibaly and S. Coulibaly, 2019. An assessment of the impact of artisanal and commercial gold mining on mercury and methylmercury levels in the environment and fish in Cote d'Ivoire. Sci. Total Environ., 665: 1158-1167.

Naswir, M. and S. Arita, 2015. Treatment of peat water using local raw material formulations of Jambi, Indonesia. Asian J. Chem., 5: 43-46.

Pawar, R.R., H.C. Bajaj and S.M. Lee, 2016. Activated bentonite as a low-cost adsorbent for the removal of $\mathrm{Cu}$ (II) and $\mathrm{Pb}$ (II) from aqueous solutions: Batch and column studies. J. Ind. Eng. Chem., 34: 213-223.

Toor, M., B. Jin, S. Dai and V. Vimonses, 2015. Activating natural bentonite as a cost-effective adsorbent for removal of Congo-red in wastewater. J. Ind. Eng. Chem., 21: 653-661.

Zheng, H., D. Liu, Y. Zheng, S. Liang and Z. Liu, 2009. Sorption isotherm and kinetic modeling of aniline on Cr-bentonite. J. Hazard. Mater., 167: 141-147. 